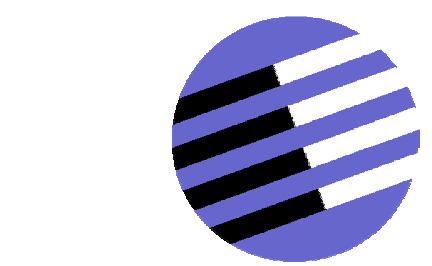

GOVERNANCE AND THE EFFICIENCY

OF ECONOMIC SYSTEMS

GESY

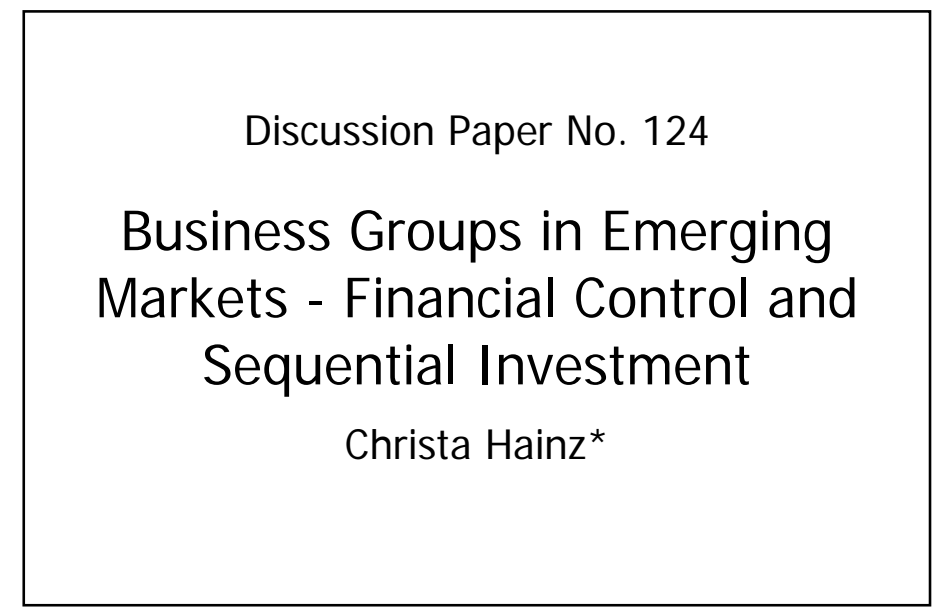

June 2006

*Christa Hainz, Department of Economics, University of Munich, Akademiestr. 1/III, 80799 Munich, Tel.: +49 892180 3232, Fax.: +49 892180 2767, christa.hainz@Irz.uni-muenchen.de

Financial support from the Deutsche Forschungsgemeinschaft through SFB/TR 15 is gratefully acknowledged. 


\title{
Business Groups in Emerging Markets - Financial Control and Sequential Investment
}

\author{
Christa Hainz* \\ University of Munich, CESifo and WDI
}

June 2006

\begin{abstract}
Business groups in emerging markets perform better than unaffiliated firms. One explanation is that business groups substitute some functions of missing institutions, for example, enforcing contracts. We investigate this by setting up a model where firms within the business group are connected to each other by a vertical production structure and an internal capital market. Thus, the business group's organizational mode and the financial structure allow a self-enforcing contract to be designed. Our model of a business group shows that only sequential investments can solve the ex post moral hazard problem. We also find that firms may prefer not to integrate.

JEL-Classification: G31, G32, G34, K49, L22
\end{abstract}

Keywords: Business groups, self-enforcing contract, institutions, internal capital market

*Department of Economics, University of Munich, Akademiestr. 1/III, 80799 Munich, Tel.: +49 892180 3232, Fax.: +49 892180 2767, e-mail: christa.hainz@lrz.uni-muenchen.de. The author would like to thank two anonymous referees, Basak Akbel, Kira Börner, Julia Förderer, Raja Kali, Isabelle Kronawitter, Steffen Lippert, William Pyle, Monika Schnitzer, Natalya Volchkova as well as seminar participants at the University of Munich, the ESEM in Stockholm, the EEA in Madrid and the ICCEES World Congress in Berlin for helpful comments and suggestions. The usual disclaimer applies. Financial support by FOROST (Forschungsverbund Osteuropa) and by the Deutsche Forschungsgemeinschaft through SFB/TR 15 is gratefully acknowledged. 


\section{Introduction}

In his famous essay, Gerschenkron (1962) argues that, in relatively backward countries, the productive and organizational structures differ from those in established industrial countries. Business groups are among the organizational structures that dominate many emerging markets. They are a "[...] collection of firms bound together in some formal and/or informal ways." (Granovetter, 1994, p. 454). Business groups take very different forms, depending on the institutional and economic conditions in which they operate. In some groups, cross shareholding is the main characteristic, whereas in others a bank plays the central role. In Russia, for instance, business groups emerged around banks that establish common financial control by means of their lending practice. Thus, these groups are hybrid organizational forms between firm and market. There is widespread evidence that business groups in emerging markets perform better than unaffiliated firms.

It has been conjectured that business groups can be advantageous because they are substitutes for missing institutions (Khanna, 2000). We provide a theoretical explanation of how business groups can act as substitutes for missing institutions such as contract enforcement. Based on stylized facts on Russian business groups, we study the case of vertically related firms and the involvement of an external lender. We demonstrate that sequential investment may solve the underinvestment problem resulting from ex post moral hazard. Our analysis also shows that firms can have an incentive not to integrate but instead to form a business group where decisions about production and investment are taken by legally independent firms.

We use a two-period model to analyze the features of a self-enforcing contract in a business group. A vertical chain of monopolies is considered in which the production choice and the decision to undertake a cost-cutting investment by one firm results in an externality for other firms. The firms decide to form a business group with a bank that provides loans to finance cost-cutting investments and exerts common financial control. Each firm can invest in cutting costs. However, in the first period, institutions are deficient because contracts cannot be enforced by law. An ex post moral hazard problem therefore exists in the case of debt financing as firms have an incentive to default strategically. Only in the second period have legal institutions improved and contracts are enforceable. In a business group, the firms are connected through the internal capital market. An additional externality thus arises as the bank only finances projects in the second period if the loan made in the first period is repaid.

The first result of our analysis is that these two externalities (created by the cost-cutting investment and by the internal capital market) can be used to solve the ex post moral hazard problem if investments are undertaken sequentially: con- 
sider a firm that receives credit from the bank in the first period for a cost-cutting investment. If this firm defaults, investment by another firm in this vertical production chain will not be financed by the bank in the second period. This means that the defaulting firm does not enjoy a higher profit in the second period because, in this case, the cost-cutting investment is not made by the other group member. This gives the firm an incentive to repay in the first period. The second result is that it can be efficient not to integrate. We show that relying on the externalities present in a business group allows the firms to design a self-enforcing contract that solves the ex post moral hazard problem in the first period. Thus, a business group can provide credit finance in the first period. In contrast, an integrated firm, in which decisions about production and investment are centralized, does not get a loan in the first period. The reason is that contract enforcement possibilities are missing and that due to the integrated structure there are no externalities that allow for a self-enforcing contract.

This paper is related to different areas in the literature: business groups, internal capital markets, sequential investment, vertical disintegration and ex post moral hazard. There are numerous empirical studies of business groups but only a few theoretical contributions. The empirical studies demonstrate that the performance of business groups in emerging markets is superior to that of unaffiliated firms (e.g. Khanna and Palepu, 1999, Perotti and Gelfer, 2001, Recanatini and Ryterman, 2000). In his survey, Khanna (2000) suggests four different ways for improving group performance. Business groups can expropriate minority shareholders, engage in rent-seeking, or exert market power. ${ }^{1}$ In these cases, business groups increase their payoff at the expense of other actors. Most importantly, however, business groups can enhance efficiency by reducing market imperfections. $^{2}$ In emerging markets, internal product, labor, and capital markets can foster efficiency since outside markets function imperfectly. ${ }^{3}$

There are a few papers that study business groups in an economy with weak institutions. In a general equilibrium model, Kali (1999) analyzes how business networks can substitute for functioning institutions. This model shows that the network absorbs honest agents and thereby has a negative impact on the anony-

\footnotetext{
${ }^{1}$ In a model of monopolistic competition, Feenstra, Huang and Hamilton (2003) study firms that can integrate horizontally or vertically. They not only study the formation of business groups but market structure in general and show that multiple equilibria can arise with either high or low concentration.

${ }^{2}$ Therefore, an important conclusion of the survey is: "It is perhaps sensible to see groups acting as substitutes for missing institutions, which would normally facilitate the functioning of markets, in the economy (...)." (Khanna, 2000, p. 754) Therefore, business groups performing this function are called "paragons" by Khanna and Yafeh (2005).

${ }^{3}$ Pyle (2002) shows that the lack of contract enforcement together with missing credit registers reduces the scale of commercial lending.
} 
mous market where transactions are insufficiently protected by legal institutions. Kali (2002) models the transition from relational contracting to arms-length explicit contracting that takes place when market intermediaries and institutions develop. In this model, business groups are used for relational contracting. The result here is that, during the transition period when institutions work imperfectly, the two modes of contracting complement one another. In Ghatak and Kali (2001), banks cannot observe a firm's productivity type when they decide on refinancing. Information is obscured in a business group due to cross-debt payment guarantees. The authors show that banks can offer a menu of contracts and firms will sort according to their risk characteristics. Kim (2004) studies a bank's decision to refinance a defaulting firm. It is demonstrated that firms in business groups are more likely to be refinanced than stand-alone firms. Banks are often members of a business group where funds are allocated through an internal capital market.

There are several papers analyzing theoretically the effects of internal capital markets. ${ }^{4}$ Some of them emphasize the bright side of internal capital markets, for example, that headquarters optimize the allocation of funds by reallocating cash flow across divisions (Stein, 1997). ${ }^{5}$ However, this "winner-picking" policy also has a dark side. ${ }^{6}$ The ex ante incentive of a divisional manager may suffer if he anticipates that cash flow generated in this division will be reallocated by the headquarters (Brusco and Panunzi, 2005). ${ }^{7}$ The theoretical literature on internal capital markets hardly considers institutional imperfections that play an important role in emerging markets. One notable exception is Almeida and Wolfenzon (2006b) who point out the negative effect of winner-picking on social welfare. Due to better information within business groups, capital is allocated internally. Thereby, the supply of funds for the external market decreases. Thus, projects that are more productive than those financed within a business group may not be undertaken.

The choice between sequential and simultaneous investment has been studied in an incomplete contract framework; through sequential investment, a complete contract can be written on the investment in the second period. Smirnov and Wait (2004a, 2004b) find that sequential investment improves the firm's incentive

\footnotetext{
${ }^{4}$ The ownership of business groups is often organized as a pyramidial structure. Recent papers provide theoretical explanations for this phenomenon and empirical evidence (Almeida and Wolfenzon, 2006a; Bianco and Nicodano, 2006).

${ }^{5}$ The reallocation of resources within a group influences the firms' behavior on the product market (Cestone and Fumagalli, 2005).

${ }^{6}$ Moreover, power struggles and lobbying are value-destroying effects of internal capital markets.

${ }^{7}$ The redistribution of cash flows may give rise to soft budget constraints. For a recent survey see Dewatripont and Roland (2000).
} 
to invest in the second period but reduces its incentive to invest in the first period. Moreover, sequential investment delays the completion of the project. While in their model sequential investment leads to a delay, we find that only sequential investment allows investment in the first period as this can constitute a self-enforcing contract.

In the literature, vertical disintegration often is interpreted as a commitment device (Crémer, 1995; Graciano, 1995; Chen, 2005). In Graciano (1995), for example, the probability that a supplier will experience a delay in the production schedule is observable only within a firm. Hence, a buyer may renegotiate the contract with its in-house seller if the latter experiences a delay. Anticipating this, the seller's incentive to deliver on time suffers. Through vertical disintegration the buyer commits to terminate the project if the supplier is not able to complete it within the original budget limits. In our model, forming a business group is preferred to integration if its costs, which are the distortions of the output decisions, are overcompensated by the cost-cut in the first period. A cost-cutting investment already in the first period is only possible in a business group when it solves the ex post moral hazard problem through establishing a self-enforcing contract.

The set-up of our model is closest to the analysis by Bolton and Scharfstein (1990). They study the ex post moral hazard problem of financing if it is impossible to enforce a debt contract that is contingent on profit. In a two-period setting, the investor will refinance the firm in the second period only if the firm repays its loan in the first period. This repayment has to be high enough to cover the investor's expected loss from financing in the second period. Like Bolton and Scharfstein, we focus on problems of contract enforcement. Therefore, we do not factor in problems of asymmetric information between creditor and debtor. Our analysis departs from the Bolton-Scharfstein model by incorporating several firms. We derive the organizational structure, the sequencing of investments and the terms of the credit contract that constitute a self-enforcing contract. In this theoretical framework, we point out the advantage which an internal capital market may have in an economy with imperfect institutions.

The paper is organized as follows. In section 2, we provide an example of business groups in emerging markets by describing the specific economic and institutional environment in Russia and the way business groups operate there. In section 3, the model of a business group is presented. We characterize the organizational structure, the sequencing of investment, and the terms of the credit contract. Both the optimal sequencing of investment and the incentive to integrate are discussed in section 4 . Section 5 concludes. 


\section{Business Groups in Russia}

In a transition country like Russia many institutions that normally support the functioning of markets in an economy are missing. As a starting point for our model, we describe the economic and institutional framework faced by Russian firms and the characteristics of Russian business groups.

Russia's industrial structure is inherited from central planning. It was, and to a large degree still is, characterized by high vertical dependence and geographical segmentation. Vertical dependence between firms is so strong that "each firm in the chain may be acting as both a monopsonist and a monopolist" (Brown et al, 1993, p. 30f). This structure was created by the industrial ministries that thought of an economy as processes along an assembly line (Brown et al, 1993). Geographical segmentation is due to the fact that regional authorities were responsible for planning the less important commodities. Therefore, after planning was abandoned the markets that emerged remained local. This structure is difficult to change: the underdevelopment of the transportation system imposes significant barriers to trade (Broadman, 2001, Avdasheva, 2002). The credit market shows similar characteristics. In many regions, the successor of the former state-owned bank continues to dominate the local market (Claeys, Schoors and Lanine, 2005).

Legal institutions in Russia are deficient in many respects. Public contract enforcement in Russia is still rather difficult. There is a serious lack of juridical infrastructure. For example, there are only one fifth as many legal professionals per capita as in western legal cultures (Blankenagel, 2000). As a result, it takes a long time for a verdict to be made. Moreover, there are substantial costs of going to court (Greif and Kandel, 1995). After a verdict is made, the seizure of assets through the bailiff service can take an additional several months (Kahn, 2002). ${ }^{8}$ It is therefore not surprising that many Russian firms do not rely on public contract enforcement; among 269 firms interviewed only 55.5 per cent believe that courts can enforce contracts (Johnson, McMillan and Woodruff, 2002). Alternative mechanisms have evolved to circumvent the legal system. The so-called "integrated business group (IBG)" can be used as one example.

At first sight, the term IBG may seem contradictory and misleading. We therefore contrast IBGs with other organizational forms. Firms in an IBG remain legally independent. Thus, they are not vertically integrated. However, they cooperate more intensively than firms in "industrial networks" (Avdasheva, 2002). One of the mechanisms that ties these firms together is common financial control.

\footnotetext{
${ }^{8}$ Kahn (2002) argues that the bailiff's incentives for addressing cases where the value of a claim is substantial are destroyed by the wage structure. Moreover, bailiffs are poorly supervised and their endowment, e.g. with telephones and computers, is insufficient.
} 
This may include a system of selective credit financing (Avdasheva et al, 2000). Dynkin and Sokolov (2002) even see the development of own financial structures as a particular characteristic of IBGs.

One important player in some IBGs was Incombank. ${ }^{9}$ The bank exerted common financial control over firms. In most cases, Incombank did not hold a controlling equity stake in these firms but exerted control through financing investments (Avdasheva, 2000). For instance, Incombank was a member of "Morskaya Tekhnika", a Financial-Industrial-Group (FIG) which is a particular form of an IBG (Evnevich, 2004). ${ }^{10}$ "Morskaya Tekhnika" was founded in order to construct submarines. The main idea was that the bank can control and direct financial flows along the whole production chain, from the exploitation of natural resources to the sale of final products (Zinin, 1996). Moreover, the loans granted were supposed to improve the efficiency of the firms in the group (Media Monitoring Integrum, 1996).

Perotti and Gelfer (2001) study the effects on firm performance of membership in a Financial-Industrial-Group (FIG). The authors discriminate between bankled and industry-led FIGs and non-group firms. They observe that there is a negative correlation between internal finance and investment in bank-led groups. These results suggest that there is substantial financial reallocation in bank-led FIGs. However, the average investment does not differ substantially among the three subgroups. Finally, Perotti and Gelfer (2001) deduce that bank-led FIGs allocate capital comparatively better than other firms. The sensitivity of investment to Tobin's Q is positive and significant only in that subgroup. The positive effect of membership in a commercial group, such as a FIG, is confirmed by a recent study (Pyle, 2006). Pyle's study shows that members of commercial groups invest significantly more in new technologies or new modes of production, and more often have growing output and sales and greatly improved financial performance, than non-members do. An explanation for their success is that firms in FIGs have better access to credit. For them, bank lending depends less on the predictability of law enforcement. This result is interpreted as evidence that business groups are substitutes for judicial enforcement of contracts (Shvets, 2006).

\section{Model of a Business Group}

\subsection{Model}

Our model captures the main features of the Russian economy in the following way. We consider a two period model. In the first period the institutions are

\footnotetext{
${ }^{9}$ However, Incombank failed after the financial crisis in 1998.

${ }^{10}$ For a detailed analysis of FIGs see Johnson (1997).
} 
still imperfect. For the investor, this means that repayment cannot be enforced by going to court. This gives rise to ex post moral hazard. In the second period, the institutions have improved and contracts are enforceable. This is common knowledge. Consequently, no problem of ex post moral hazard arises. To simplify the analysis, there is no discounting.

To capture the imperfect competitive environment, we consider a model with a chain of monopolies. The chain of monopolies reflects the externalities between producers in a business group. The monopolistic producer of the intermediate good is called manufacturer $M$. $M$ produces an intermediate good at constant marginal costs of $c$ and sets a price $p_{M}$. The retailer $R$, who is also a monopolist, then faces a marginal cost for his input (the intermediate good) of $p_{M}$. In addition, the retailer incurs constant marginal costs of $k$ per unit, e.g. for servicing customers. The retailer sets a price $p$. The final demand function is $D(p)=1-p$. Solving the game by backward induction, it is straightforward to show that the manufacturer produces $q=\frac{1-c-k}{4}$ units of the intermediate good which is sold to the retailer at a price of $p_{M}=\frac{1+c-k}{2}$. Thus, the manufacturer's profit is $\Pi^{M}=\frac{(1-c-k)^{2}}{8}$. The retailer sells these goods at a price of $p=\frac{3+c+k}{4}$ and gets a profit of $\Pi^{R}=\frac{(1-c-k)^{2}}{16}$. In this standard model of a vertical structure, double marginalization is responsible for a production level that is even lower than in the monopoly case and, thus too low from a social welfare perspective.

Both firms can invest in order to reduce their costs and this, in turn, increases the quantity supplied in equilibrium. If the manufacturer invests $I^{M}$, its costs decrease from $c_{H}$ to $c_{L}$. The retailer achieves a cost cut from $k_{H}$ to $k_{L}$ if he invests $I^{R}$. Due to the vertical structure, the investment decision of $M$ exerts an externality on $R$ (and vice versa). We assume that carrying out the investment is efficient in the sense that the sum of additional profits generated by both firms in both periods exceeds the costs of investment. Furthermore, we assume that $c_{H}+k_{H} \leq 1$.

$M$ and $R$, together with other firms, some of which have excess funds, decide to form a business group. The crucial feature of this business group is that it has a common bank $B$ that makes financial decisions. $B$ collects excess funds and grants credit to firms within the business group that need financing. $B$ can commit to financing even if, in the short run, the repayment does not cover the amount of credit granted. ${ }^{11}$ In our model, the bank commits in the first period to finance a firm in the second period even though granting the loan might yield a loss. However, $B$ also faces a zero-profit constraint in the long run. Thus, $B$ establishes central financial control. The members of the business group have

\footnotetext{
${ }^{11}$ Usually, the bank owns shares of the firms in the group. It is therefore interested in costcutting investments.
} 
better information about each other than outsiders do. One reason could be that they have interacted previously. To capture this idea in the simplest way we assume that information between group members is symmetric. Due to enormous informational asymmetries, there is no financing from outside investors. Since neither $M$ nor $R$ get credit from outside banks, $B$ has a monopoly in financing them.

\subsection{Ex Post Moral Hazard and Market Failure}

We start by investigating the loan granted by $B$ in a business group in a one period framework. Suppose that $B$ grants credit in the amount of $I^{M}$ to $M$ in the first period when the institutions are still imperfect. $M$ is always better off by defaulting. As $B$ anticipates this opportunistic behavior it does not grant credit at all. Thus, no investment is made because the ex post moral hazard problem cannot be solved in a one period framework (Bolton and Scharfstein, 1990). This result implies that it is also impossible to finance both investments $I^{M}$ and $I^{R}$ in the first period.

Next, we show that credit will only be granted if a self-enforcing contract can be designed. In order to keep the analysis as simple as possible we study a model with two periods, where functioning institutions are in place in the last period. ${ }^{12}$ In our case, a contract is self-enforcing if the sequencing of the investment decisions is chosen appropriately. ${ }^{13}$ From the result above, it is evident that the investment projects have to be financed sequentially. We derive both possible sequences of investments and check whether they solve the ex post moral hazard problem. First, we analyze the case where investment in the first period is undertaken by $M$ and in the second period by $R$. Second, we analyze the case where investment is undertaken by $R$ in the first period and by $M$ in the second period. In the next section, we discuss the optimal sequencing.

\footnotetext{
${ }^{12}$ The evidence from transition countries shows that after a decade of transition, the "law on the books" has developed much faster than law enforcement (EBRD, 2004). Thus, the improvement in the institutional environment can be seen as a gradual development. In a multi-period model, contract enforcement has to work only in the last period.

${ }^{13} \mathrm{An}$ alternative solution might be that firms interact repeatedly on the product market and punish the firm that did not repay. However, in emerging markets the uncertainty is very high and therefore firms expect that repeated interaction with a particular partner occurs only with a certain probability. Moreover, interaction may take place only infrequently. Therefore, it is difficult to establish a long-term relationship with reputation effects.
} 


\subsection{Case I: M Invests in the First Period}

The time structure of this model that features two periods of production is as follows: before the financial decisions are made, $M, R$ and the other firms decide about forming a business group. Then, $B$ makes a take-it-or-leave-it credit offer to $M$. In the first period, $M$ invests if he is awarded the funds. Next, $M$ decides on the price for the intermediate good, and $R$ determines its price. The prices determine the production level. At the end of period 1, $M$ either repays $B$ or defaults, depending on which action maximizes profit. After $M$ 's action, $B$ can decide about financing $R$. In the second period, $R$ invests. Both the firms $M$ and $R$ set second-period prices and make their production decisions. The time structure is illustrated in Figure 1.

\section{[Figure 1]}

In order to derive a self-enforcing investment contract that ensures the costcutting we need the following assumptions that guarantee that the firms are not able to self-finance the investment or do not have an incentive to do so:

Assumption I1: $\frac{1}{16}\left(\left(1-c_{L}-k_{L}\right)^{2}-\left(1-c_{L}-k_{H}\right)^{2}\right)<I^{R}$

Assumption I2: $\frac{3}{16}\left(\left(1-c_{L}-k_{L}\right)^{2}-\left(1-c_{L}-k_{H}\right)^{2}\right)>I^{R}$ and

$\frac{3}{8}\left(\left(1-c_{L}-k_{H}\right)^{2}-\left(1-c_{H}-k_{H}\right)^{2}\right)>I^{M}$

Assumption I3: $\frac{3\left(1-c_{L}-k_{H}\right)^{2}}{16}<I^{R}$

Assumption $I 1$ says that the additional profit for $R$ generated through investment $I^{R}$ in the second period is lower than the investment needed. This implies that $R$ would not self-finance the investment and that the bank would not finance only $I^{R}$. According to assumption I2, each investment increases the joint profits of $M$ and $R$ by more than the investment costs. Thus, it is profitable for $R$ and $M$ to undertake investment $I^{R}$. The reason that the impact of investment on profit for $R$ differs from the impact on the joint profit of $R$ and $M$ is the externality that results for $M$ from the investment by $R$ because of the vertical structure. Note that the profit generated by $I^{M}$ is higher as the cost cut is already realized in the first period. Assumption I3 states that the sum of profits generated by $R$ and $M$ in the first period are too low to cover the costs of investment in the second period.

Figure 2 depicts the threshold values of $I^{R}$. The upper threshold value is determined by assumption I2. The lower threshold value is determined either by assumption I1 or I3. Figure 2 a shows the parameter range when assumption I1 is binding whereas figure $2 \mathrm{~b}$ shows the parameter range when $I 3$ is binding. Whether assumption $I 1$ or I3 describes the lower threshold value depends on the size of $k_{H}$. The higher $k_{H}$, the less likely it is that assumption $I 3$ constitutes the threshold value. 


\section{[Figure 2]}

The following proposition describes the credit contract offered, i.e. the repayment in period 1 , denoted by $Z_{1}^{M}$, and that in period 2 , denoted by $Z_{2}^{R}$.

Proposition 1. In case $I$, the bank $B$ offers credit only if the repayment in period 1 is $Z_{1}^{M} \geq I^{R}+I^{M}+\frac{\left(1-c_{L}-k_{H}\right)^{2}}{16}-\frac{\left(1-c_{L}-k_{L}\right)^{2}}{16}$. In period 2, it demands as a repayment $Z_{2}^{R}=\frac{\left(1-c_{L}-k_{L}\right)^{2}}{16}-\frac{\left(1-c_{L}-k_{H}\right)^{2}}{16}$.

Proof: See the Appendix.

We assumed that $R$ would never use equity to finance its investment $I^{R}$ because the profit generated is too low (Assumption I1). ${ }^{14}$ However, the investment is profitable for the group due to the strong externality that $I^{R}$ causes for $M$ (Assumption I2). According to Proposition 1, the repayment $Z_{2}^{R}$ that $B$ demands in the second period cannot exceed the amount investment $I^{R}$ adds to the profit of $R .{ }^{15}$ Otherwise, it would hurt $R$ 's participation constraint (PC-R). $B$ extracts the additional profit because it exerts its monopoly power. However, this repayment does not cover investment $I^{R} ; B$ makes an expected loss. $B$ grants credit only if the loss in the second period is covered by the repayment from $M$ in the first period. Thus, $M$ has to subsidize $R$ 's investment in the second period. Proposition 2 shows when this contract is feasible.

Proposition 2. In case I, forming a business group solves the ex post moral hazard problem if $\frac{3}{16}\left(\left(1-c_{L}-k_{L}\right)^{2}-\left(1-c_{L}-k_{H}\right)^{2}\right) \geq I^{R}+I^{M}$ and $\frac{1}{16}\left(\left(1-c_{L}-k_{L}\right)^{2}+\left(1-c_{L}-k_{H}\right)^{2}\right) \geq I^{R}+I^{M}$.

\section{Proof: See the Appendix.}

The driving forces for this solution are the two externalities. First, due to the vertical structure, $R$ 's investment has a positive effect on $M$ 's profit. As $I^{R}$ decreases $R$ 's costs to $k_{L}$, the quantity sold increases and, consequently, the profits of both $R$ and $M$ increase. Second, default by $M$ results in a negative externality on $R$. If $M$ does not repay, $B$ does not grant credit to $R$ in the second period because it would make an expected loss. Accordingly, $M$ anticipates that his default prevents $R$ from investing in a cost-cutting technology, and that he loses the

\footnotetext{
${ }^{14}$ This is also the reason $R$ does not contribute its profit generated in period 1 to reduce the amount of credit needed in period 2.

${ }^{15}$ In Bolton and Scharfstein (1990) only a proportion of the profit is verifiable. In contrast, in our analysis, the increase in profit in the second period is contractible as institutions function perfectly. However, the results generated in our model would still be obtained if only a proportion of the profit is contractible.
} 
potential increase in his own profit $\Pi^{M}$. For the conditions given in Proposition 2 , it is optimal for $M$ to repay. Note that if $\left(1-c_{L}-k_{L}\right)^{2}>2\left(1-c_{L}-k_{H}\right)^{2}$ and the liquidity constraint of $M$ is fulfilled, $M$ 's incentive compatibility constraint always holds. For this parameter constellation, $R$ 's cost reduction has the additional effect of reducing $M$ 's incentive to default because, in the case of default, $M$ would not enjoy an increased profit in the second period.

Lower investment expenditures increase the parameter range in which a selfenforcing contract is feasible. However, it is important to note that $I^{R}$ has to exceed a certain threshold as defined in Assumption I1 and I3 respectively in order to establish an ex post moral hazard problem. $M$ 's incentive to repay increases as $k_{L}$ decreases because lower costs of $R$ increase $R$ 's demand for the intermediate good and thereby $M$ 's profit in the second period.

\subsection{Case II: R Invests in the First Period}

Next, we study the reversed timing of investments. In this scenario, $R$ invests in the first period and $M$ in the second. All other actions remain the same as before. Figure 3 illustrates the timing of events.

[Figure 3]

Assumption II1: $\frac{1}{8}\left(\left(1-c_{L}-k_{L}\right)^{2}-\left(1-c_{H}-k_{L}\right)^{2}\right)<I^{M}$

Assumption II2: $\frac{3}{16}\left(\left(1-c_{L}-k_{L}\right)^{2}-\left(1-c_{H}-k_{L}\right)^{2}\right)>I^{M}$ and

$\frac{3}{8}\left(\left(1-c_{H}-k_{L}\right)^{2}-\left(1-c_{H}-k_{H}\right)^{2}\right)>I^{R}$

Assumption II3: $\frac{3}{16}\left(1-c_{H}-k_{L}\right)^{2}<I^{M}$

According to assumption $I I 1$, the additional profit generated by $M$ is too low to cover the costs of investment $I^{M}$. Still, both investments increase the joint profit of $M$ and $R$ by an amount that is higher than the costs of investment (Assumption II2). Assumption II3 states that the firms do not have enough liquid means to finance $I^{M}$ themselves in the second period.

Analogously to Proposition 1 the third proposition describes the credit contract offered by $B$.

Proposition 3. In case $I I, B$ grants credit only if the repayment in period 1 is $Z_{1}^{R} \geq I^{R}+I^{M}+\frac{\left(1-c_{H}-k_{L}\right)^{2}}{8}-\frac{\left(1-c_{L}-k_{L}\right)^{2}}{8}$. In period 2, it demands as a repayment $Z_{2}^{M}=\frac{\left(1-c_{L}-k_{L}\right)^{2}}{8}-\frac{\left(1-c_{H}-k_{L}\right)^{2}}{8}$.

In period 2, $M$ 's additional profit generated by the investment is insufficient to cover the costs of investment. Therefore, $M$ would not self-finance the investment project. The loss that $B$ makes with this investment has to be covered by $R$ 's 
first period repayment. Proposition 4 determines the parameter values for which offering this contract solves the ex post moral hazard problem.

Proposition 4. In case II, forming a business group solves the ex post moral hazard problem if $\frac{3}{16}\left(\left(1-c_{L}-k_{L}\right)^{2}-\left(1-c_{H}-k_{L}\right)^{2}\right) \geq I^{R}+I^{M}$ and $\frac{1}{16}\left(2\left(1-c_{L}-k_{L}\right)^{2}-\left(1-c_{H}-k_{L}\right)^{2}\right) \geq I^{R}+I^{M}$.

Proof: See the Appendix.

As before, the interaction of the two externalities can be exploited by $B$ to design a self-enforcing contract. $R$ 's decision to repay influences $M$ 's opportunity to invest, and therefore increases its own profit because $M$ 's investment increases $\Pi^{R}$ too. $^{16}$

The results in Proposition 2 and 4 show that the cost reduction in the second period plays a crucial role. In case $I, M$ has an incentive to repay if the cost reduction by the second period investment $I^{R}$ exceeds the crucial value described in Proposition 2. In contrast, in case $I I$, the cost reduction by $I^{M}$ has to be high enough to give $R$ an incentive to repay. In general, the larger the cut in costs in period 2, the higher the externality that increases the second-period profit of the firm investing in period 1 . Hence, the incentive to repay in period 1 increases. Comparing the results in the two cases reveals that the externality caused by the second-period investment is higher in case I where $R$ invests in period 2 .

The theoretical analysis of the non-integrated business group has shown that the externality that investment of $M$ places on $R$ provides an incentive for $M$ to repay (and vice versa). In an integrated structure, these externalities would disappear, and with them, M's incentive to repay. Thus, a self-enforcing contract solving the ex post moral hazard problem would not be feasible in such an organizational setting.

\section{Discussion of Results}

\subsection{Optimal Sequencing}

The arguments above have shown that the type of contract, in particular the sequencing of investments, depends crucially on the characteristics of the projects, as described by the parameter constellations. When designing a contract, three restrictions have to be considered. They are described in general terms here. First,

\footnotetext{
${ }^{16}$ If the cost-cutting effect of $M$ 's investment is such that $\left(1-c_{L}-k_{L}\right)^{2}>2\left(1-c_{H}-k_{L}\right)^{2}$, $R$ 's incentive compatibility constraint always holds, provided that $R$ 's liquidity constraint is fulfilled.
} 
profits generated in both firms in the first period must not exceed the investment expenses in the second period (Assumption 3). Otherwise, the firms could join forces and self-finance the second-period investment. Under these circumstances, the firm investing in the first period would no longer have an incentive to repay. Hence, no credit would be granted in the first period.

Second, the profit generated in the firm which invests in the first period has to be high enough to cover the repayment that $B$ needs to break even (LC). Since the bank makes an expected loss in the second period, it must obtain a positive profit in the first period. The bank's second-period loss, which has to be covered by the firm that invests in the first period, can be interpreted as a subsidy for the firm investing in the second period. The more the profit of the firm investing in the second period increases by second period investment, the lower the subsidy needs to be.

Third, the firm investing in the first period must have an incentive to repay (IC). Generally, this firm decides either to repay, and thereby subsidize the firm investing in the second period, or to default. The incentive compatibility constraint, which guarantees that the firm investing in the first period repays its loan, is fulfilled more easily if the cost-cutting effect of the second period investment is higher than that in the first period. This implies that the externality from the second period investment is higher. Therefore, investment made in the second period increases the profit of the firm that has invested in the first period more strongly. Moreover, the profit of the firm that invests in the second period is higher and therefore the subsidy needed is lower. This makes the liquidity constraint of the firm investing in the first period less demanding too.

These arguments apply regardlessly of whether $M$ or $R$ invests in the first period. They already show a potential tension in the sequencing of investments. When determining the sequence of investment, the business group faces the following trade-off. The business group wants to ensure the possibility of investing in the first period at all by solving the ex post moral hazard problem through the appropriate sequencing. However, this might imply that it has to postpone the investment that cuts costs most strongly to the second period. The trade-off is illustrated in the following parametrized example:

Example 1. Suppose that $I^{M}=0.0591, c_{H}=0.5, c_{L}=0.05$ and $I^{R}=0.00557$, $k_{H}=0.5, k_{L}=0.2$. In this case, a self-enforcing contract can be designed if $R$ invests in the first period and $M$ invests in the second period.

If $M$ invests in the first period and $R$ invests in the second, the contract is not self-enforcing. The reason is that the joint profit of $M$ and $R$ in the first period is high enough to finance $I^{R}$ in the second period. However, the profits 
generated would be higher if $I^{M}$ is undertaken in the first period as the cost reduction of $\Delta c=0.45$ is higher than that reached through $I^{R}$ which is given by $\Delta k=0.3$. This example shows that solving the ex post moral hazard problem may require postponing the investment which reduces costs more strongly to the second period. Facilitating investment in the first period is the dominant requirement since otherwise the cost reduction in the first period cannot be obtained. ${ }^{17}$ Of course, the optimal sequencing depends on the cost reductions reached relative to the investment needed. If the cost reduction described in example 1 can be obtained with different investments, for example, $I^{M}=0.098$ and $I^{R}=0.0379$, then the contract is self-enforcing if $M$ invests in the first period and $R$ invests in the second period.

\subsection{Incentive to Integrate}

Naturally, the question arises of why firms within the business group do not integrate in order to reduce double marginalization and, thus, increase profit. On the one hand, vertical integration would increase the group's output and thus profit to $\frac{(1-c-k)^{2}}{4}$. On the other hand, the externalities would disappear in an integrated structure, and with them, the incentive to repay of the firm investing in the first period. Thus, it is not possible to establish a self-enforcing contract solving the ex post moral hazard problem in an integrated firm. The following proposition describes the firm's decision.

Proposition 5. In Case I, it is optimal for the firms to form a business group if $3\left(1-c_{L}-k_{H}\right)^{2}-4\left(1-c_{H}-k_{H}\right)^{2}-\left(1-c_{L}-k_{L}\right)^{2} \geq 0$ provided that the conditions of proposition 2 hold. Otherwise, $M$ and $R$ integrate.

In Case II, it is optimal for the firms to form a business group if $3\left(1-c_{H}-k_{L}\right)^{2}-4\left(1-c_{H}-k_{H}\right)^{2}-\left(1-c_{L}-k_{L}\right)^{2} \geq 0$ provided the conditions of proposition 4 hold. Otherwise, $M$ and $R$ integrate.

Proof: See the Appendix.

Firms decide to integrate either if integration is more profitable (as can be seen from the conditions in proposition 5) or if it is not possible to solve the ex post moral hazard problem through forming a business group because the conditions given in proposition 2 and proposition 4 respectively fail to hold. ${ }^{18}$

\footnotetext{
${ }^{17}$ These countervailing effects also highlight the inefficiency that arises if self-enforcing contracts have to be used, as explicit contracts are not enforceable in this framework.

${ }^{18}$ Of course, remaining separate firms is dominated by either forming a business group or integrating.
} 
When deciding about whether to integrate or not, $M$ and $R$ face the following trade-off: integration definitely increases output in the second period but leads to higher production costs in the first period and thereby potentially to a lower production level. The following example is used to illustrate Proposition 5. It shows a case in which firms do not have an incentive to integrate because the profit of the business group, denoted by $\Pi^{B G}$, is higher than the profit of an integrated firm, denoted by $\Pi^{I}$.

Example 2. Suppose that $I^{M}=0.098, c_{H}=0.5, c_{L}=0.05$ and $I^{R}=0.0379, k_{H}=$ $0.5, k_{L}=0.20$. In this case, the profit of a business group is higher than that of an integrated firm, i.e. $\Pi^{B G}=0.09573>\Pi^{I}=0.09293$.

The parameters are such that financing $M$ in the first period and $R$ in the second period allow a self-enforcing contract to be designed. The total profit of the business group in both periods is $\Pi^{B G}=0.09573$. The amount of goods produced is $q_{1}^{B G}=0.1125$ in the first period and $q_{2}^{B G}=0.1875$ in the second period. An integrated firm does not produce at all in the first period, but produces $q_{2}^{I}=0.375$ in the second period. The total profit of an integrated firm amounts to $\Pi^{I}=0.09293$.

For this example, the problem of poor institutions becomes evident at once. Due to missing contract enforcement, outside creditors are reluctant to lend in the first period. The (social) costs of credit rationing can be substantial. In our example, only a small amount of credit is needed to reduce manufacturing costs dramatically. This cost reduction leads to an increase in the amount of goods produced. Integration destroys the possibility of designing self-enforcing contracts because it eliminates the externalities between $M$ and $R$. Consequently, an integrated firm is not able to finance a cost saving investment by $M$ in the first period. It can reap the benefits of lower manufacturing costs only in the second period. Thus, the total profit of an integrated firm is lower in our example.

\section{Conclusion}

We started this paper with the question of how business groups can substitute for imperfect institutions, especially where it is impossible to enforce contracts. We set up a model with vertically related firms and a bank as an external lender. The model shows how a self-enforcing contract solves ex post moral hazard of finance. The analysis reveals that vertically related firms do not integrate but instead they establish common financial control through having one bank that finances all firms within the group. 
The first result of our analysis is that firms in a business group can already invest in the first period when unaffiliated firms or integrated firms are credit rationed because of deficient institutions. Thereby our model of common financial control and sequential investment provides a potential explanation for the superior performance of business groups in Russia. They invest more in new technologies and modes of production and, as a result, are likely to grow and improve their financial performance, as is shown by Pyle (2006). The second result is that funds are reallocated within the business group. The reallocation is due to the externalities of the vertical structure which are thereby partially internalized. As a third result we show that firms can have an incentive not to integrate in order to obtain a loan already in the first period.

In emerging markets, it can take a long time for contracts to be enforced. ${ }^{19}$ However, if the self-enforcing contracts are repeated within this vertical structure until institutions that facilitate contract enforcement are in place, the moral hazard problem can be solved in several periods. Because of this argument, the positive effect of internal capital markets should increase relative to its negative effect. However, while contracts can sustain financial transactions between firms that know each other, they do not help to develop new interactions (Johnson, McMillan and Woodruff, 2002).

\footnotetext{
${ }^{19}$ According to Arrow (2000, P. 13) “(...) the readjustment of institutions is an extended process."
} 


\section{Appendix}

\subsection{Proof of Proposition 1}

Provided that $M$ has cut its costs to $c_{L}, R$ invests in the second period only if he is not worse off than without a credit financed investment. Formally, his participation constraint is

$$
\frac{\left(1-c_{L}-k_{L}\right)^{2}}{16}-Z_{2}^{R} \geq \frac{\left(1-c_{L}-k_{H}\right)^{2}}{16} .
$$

$B$ will increase $Z_{2}^{R}$ so that $R$ 's participation constraint binds. $B$ offers credit if it obtains a non-negative payoff from this two-period relationship with $M$ and $R$. After inserting the optimal $Z_{2}^{R}, B$ 's zero-profit constraint can be written as

$$
Z_{1}^{M}+\frac{\left(1-c_{L}-k_{L}\right)^{2}}{16}-\frac{\left(1-c_{L}-k_{H}\right)^{2}}{16}-I^{R}-I^{M}=0
$$

Solving for the first period repayment $Z_{1}^{M}=I^{R}+I^{M}+\frac{\left(1-c_{L}-k_{H}\right)^{2}}{16}-\frac{\left(1-c_{L}-k_{L}\right)^{2}}{16}$ is determined.

\subsection{Proof of Proposition 2}

For $M$, it has to be optimal to repay after period 1. Formally, this is expressed in its incentive compatibility constraint:

$$
\frac{\left(1-c_{L}-k_{L}\right)^{2}}{8}-Z_{1}^{M} \geq \frac{\left(1-c_{L}-k_{H}\right)^{2}}{8}
$$

or, after substituting $Z_{1}^{M}$ according to $(P C-B)$

$$
\frac{3}{16}\left(\left(1-c_{L}-k_{L}\right)^{2}-\left(1-c_{L}-k_{H}\right)^{2}\right) \geq I^{R}+I^{M} .
$$

$M$ 's incentive compatibility constraint also guarantees that he demands credit to finance the investment in period 1, i.e. that $\frac{\left(1-c_{L}-k_{H}\right)^{2}}{8}+\frac{\left(1-c_{L}-k_{L}\right)^{2}}{8}-Z_{1}^{M} \geq 0$. Moreover, the profit generated in period 1 has to be high enough to cover the repayment $Z_{1}^{M}$. The liquidity constraint is given by:

$$
\frac{\left(1-c_{L}-k_{H}\right)^{2}}{8}-Z_{1}^{M} \geq 0
$$

or, after inserting $Z_{1}^{M}=I^{R}+I^{M}+\frac{\left(1-c_{L}-k_{H}\right)^{2}}{16}-\frac{\left(1-c_{L}-k_{L}\right)^{2}}{16}$

$$
\frac{1}{16}\left(\left(1-c_{L}-k_{L}\right)^{2}+\left(1-c_{L}-k_{H}\right)^{2}\right) \geq I^{R}+I^{M} .
$$

Q.E.D. 


\subsection{Proof of Proposition 4}

The repayment must fulfill $R$ 's incentive compatibility constraint and its liquidity constraint. Repayment $Z_{1}^{R}$ is incentive compatible if

$$
\frac{\left(1-c_{L}-k_{L}\right)^{2}}{16}-Z_{1}^{R} \geq \frac{\left(1-c_{H}-k_{L}\right)^{2}}{16}
$$

or, after inserting $Z_{1}^{R}=I^{R}+I^{M}+\frac{\left(1-c_{H}-k_{L}\right)^{2}}{8}-\frac{\left(1-c_{L}-k_{L}\right)^{2}}{8}$ from $B$ 's participation constraint

$$
\frac{3}{16}\left(\left(1-c_{L}-k_{L}\right)^{2}-\left(1-c_{H}-k_{L}\right)^{2}\right) \geq I^{R}+I^{M} .
$$

This condition guarantees that $R$ prefers the credit financed investment to the outside option of no investment. In either period, credit financing is associated with a profit of $\Pi_{1}^{R}=\frac{\left(1-c_{H}-k_{L}\right)^{2}}{16}$. Moreover, $R$ 's first period profit has to be high enough to cover the repayment $Z_{1}^{R}$. Formally, $R$ 's liquidity constraint is given by:

$$
\frac{\left(1-c_{H}-k_{L}\right)^{2}}{16}-Z_{1}^{R} \geq 0
$$

or, after inserting $Z_{1}^{R}=I^{R}+I^{M}+\frac{\left(1-c_{H}-k_{L}\right)^{2}}{8}-\frac{\left(1-c_{L}-k_{L}\right)^{2}}{8}$

$$
\frac{1}{16}\left(2\left(1-c_{L}-k_{L}\right)^{2}-\left(1-c_{H}-k_{L}\right)^{2}\right) \geq I^{R}+I^{M} .
$$

Q.E.D.

\subsection{Proof of Proposition 5}

In Case I, the profits of an integrated firm in the first and the second period amount to $\frac{1}{4}\left(\left(1-c_{H}-k_{H}\right)^{2}+\left(1-c_{L}-k_{L}\right)^{2}\right)$ whereas the profits of a business group are $\frac{3}{16}\left(\left(1-c_{L}-k_{H}\right)^{2}+\left(1-c_{L}-k_{L}\right)^{2}\right)$. Comparing these two profit levels yields the condition stated in Proposition 5. In Case II, the profit of the business group would be $\frac{3}{16}\left(\left(1-c_{H}-k_{L}\right)^{2}+\left(1-c_{L}-k_{L}\right)^{2}\right)$.

Q.E.D. 


\section{References}

Almeida, Heitor and Wolfenzon, Daniel, "A Theory of Pyramidal Ownership and Family Business Groups", Journal of Finance, forthcoming, 2006a.

Almeida, Heitor and Wolfenzon, Daniel, "Should Business Groups be Dismantled? The Equilibrium Costs of Efficient Internal Capital Markets", Journal of Financial Economics 79, 99-144, January 2006b.

Arrow, Kenneth, "Economic Transition: Speed and Scope", Journal of Institutional and Theoretical Economics 156, 9-18, March 2000.

Avdasheva Svetlana, "Processing (Tolling) Contracts in Russian Industries: an Institutional Perspective", HSE Working Paper Series, WP1/2002/04, 2002, available at: http://www.hse.ru/science/preprint/WP1_2002_04.pdf

Avdasheva Svetlana, Balyukevich V., Gorbachev A. et al, "Analysis of the role of integrating structures in the Russian product markets (Analiz roli integriruemykh struktur na rossiyskikh tovarnykh rynkakh)", Moskow: TEIS Press, 2000.

Bianco, Magda and Nicodano, Giovanna, "Business Groups and Debt", European Economic Review, forthcoming, 2006.

Blankenagel, Alexander, "Legal Reforms in Russia: Visible Steps, Obvious Gaps, and an Invisible Hand?" Journal of Institutional and Theoretical Economics 156, 90-119, March 2000.

Bolton, Patrick, and Scharfstein, David S., "A Theory of Predation Based on Agency Problems in Financial Contracting" American Economic Review 80, 1:93-106, March 1990.

Broadman, Harry, "Competition and Business Entry in Russia", Finance and Development 38, 2:22-25, June 2001.

Brown, Annette N., Ickes, Barry and Ryterman, Ickes, The Myth of Monopoly: A New View of Industrial Structure in Russia, unpublished manuscript, Pennsylvania State University, 1993.

Brusco, Sandro and Panunzi, Fausto, "Reallocation of Corporate Resources and Managerial Incentives in Internal Capital Markets", European Economic Review 49, 3:659-681, 2005.

Cestone, Giacinta and Rumagalli, Chiara, "The Strategic Impact of Resource Flexibility on Business Groups", RAND Journal of Economics 36, 1:193-214, 2005 .

Chen, Yongmin, "Vertical Disintegration", Journal of Economics $\&$ Management Strategy 14, 1:209-229, 2005. 
Claeys, Sophie, Schoors, Koen and Lanine, Gleb, Bank Supervision Russian Style: Rules versus Enforcement, BOFIT Discussion Paper No. 10/2005, 2005.

Crémer, Jacques, "Arm's Length Relationships", Quarterly Journal of Economics CX, 2:275-295, 1995.

Dewatripont, Mathias and Roland, Gérard, "Soft Budget Constraints, Transition, and Financial Systems", Journal of Institutional and Theoretical Economics 156, 245-260, March 2000.

Dynkin A. and Sokolov A., "Integrated Business Groups in the Russian Economy (Integrirovannye biznes-gruppy v rossiyskoy ekonomike)", Voprosy Economiky 4, 78-95, 2002.

EBRD, Transition Report 2004: Infrastructure in Transition, EBRD: London, 2004 .

Evnevich, Maria, Managing integrated business groups in contemporary Russia (Problemy upravleniya integrirovannymi biznes-gruppami v sovremennoy Rossii), Management today 3, 2004.

Feenstra, Robert C., Huang, Deng-Shing, and Hamilton, Gary G., "A Market Power Based Model of Business Groups", Journal of Economic Behaviour and Organization 51, 459-485, 2003.

Gerschenkron, Alexander, "Economic Backwardness in Historical Perspective. A Book of Essays", Cambridge: Belknap Press of Harvard University Press, 1962.

Ghatak, Maitreesh and Kali, Raja, "Financially Interlinked Business Groups", Journal of Economics \& Management Strategy 10, 591-619, 2001.

Granovetter, Mark, "Business Groups", in: Smelser, N.J. and Swedberg, R. (Eds.), The Handbook of Economic Sociology, Princeton, Princeton University Press, 1994, pp. 453-475.

Graziano, Clara, "Cost Observability and Renegotiation", Journal of Economic Behavior and Organization 28, 359-372, 1995.

Greif, Avner and Kandel, Eugene, "Contract Enforcement Institutions: Historical Perspective and Current Status in Russia", in: Lazear, E.P. (Eds.), Economic Transition in Eastern Europe and Russia: Realities of Reform, Stanford, Hoover Institution Press, 1995, pp. 291-321.

Johnson, Juliet, "Russia's Emerging Financial-Industrial Groups", Post-Soviet Affairs 13, 4: 333 - 365, 1997.

Johnson, Simon, McMillan, John and Woodruff, Christopher, "Courts and Relational Contracts", Journal of Law, Economics, and Organization 18, 1:22177, 2002.

Kahn, Peter L., "The Russian Bailiffs Service and the Enforcement of Civil Judgments", Post-Soviet Affairs 18, 2:148-173, 2002. 
Kali, Raja, "Contractual Governance, Business Groups and Transition", Economics of Transition 10, 2:255-272, 2002.

Kali, Raja, "Endogenous Business Networks", Journal of Law, Economics, and Organization 15, 3:615-636, 1999.

Khanna, Tarun, "Business Groups and Social Welfare in Emerging Markets: Existing Evidence and Unanswered Questions", European Economic Review 44, 748-761, 2000.

Khanna, Tarun and Palepu, Krishna, "Is Group Affiliation Profitable in Emerging Markets? An Analysis of Diversified Indian Business Groups", Journal of Finance LV, 2:867-891, April 2000.

Khanna, Tarun and Yafeh, Yishay, Business Groups in Emerging Markets: Paragons or Parasites?, CEPR Discussion Paper No. 5208, London: Center for Economic Policy Research, September 2005.

Kim, Se-Jik, "Bailout and Conglomeration", Journal of Financial Economics 71, 315-347, 2004.

Media Monitoring Integrum, The first-rate private bank of Russia Inkombank was eight years on November 11th (11 noyabrya krupneyshemu negosudarstvennomu banku Rossii - Inkombanku ispolnilos' vosem' let), 11.11.1996, in: Integrum Media Monitoring, Banks and Banking 1996-1999, http://www.integrum.ru (22.05.2006).

Perotti, Enrico and Gelfer, Stanislav, "Red Barons or Robber Barons? Governance and Investment in Russian Financial-Industrial Groups", European Economic Review 45, 1601-1617, 2001.

Pyle, William, "Collective Action and Post-Communist Enterprise: The Economic Logic of Russia's Business Associations", Europe-Asia Studies, forthcoming, 2006.

Pyle, William, "Overbanked and Credit-Starved: A Paradox of the Transition", Journal of Comparative Economics 32, 1:26-51, 2002.

Recanatini, Francesca and Ryterman, Randi, Disorganization or Self-Organization, unpublished manuscript, World Bank: Washington DC, 2000.

Smirnov, Vladimir and Wait, Andrew, "Hold-up and Sequential Specific Investment", RAND Journal of Economics 35, 2:386-400, 2004a.

Smirnov, Vladimir and Wait, Andrew, "Timing of Investment, Holdup and Total Welfare", International Journal of Industrial Organization 22, 413-425, 2004b.

Shvets, Julia, "Law Enforcement and Firms' External Finance: Evidence from Russian Commercial Courts", unpublished manuscript, April 2006.

Stein, Jeremy, "Internal Capital Markets and the Competition for Corporate Resources", Journal of Finance 52, 1:111-133, 1997. 
Zinin, Evgeniy, Morskaya Tekhnika united Financiers and producers (Morskaya tekhnika obedinila finansistov i promyshlennikov), Delovoy Peterburg 17 (186), 12.03.1996. 


\begin{tabular}{|c|c|c|c|c|}
\hline $\begin{array}{l}\text { - Firms } \\
\text { decide on } \\
\text { forming a } \\
\text { business } \\
\text { group } \\
\text { - B makes } \\
\text { take-it-or- } \\
\text { leave-it- } \\
\text { credit } \\
\text { offer to M }\end{array}$ & $\begin{array}{l}\text { - M decides } \\
\text { on invest- } \\
\text { ment } \\
\text { - M decides } \\
\text { on price } \\
\text { - R decides } \\
\text { on price }\end{array}$ & $\begin{array}{l}\text { - M decides } \\
\text { whether or } \\
\text { not to } \\
\text { repay } \\
\text { - B decides } \\
\text { whether or } \\
\text { not to } \\
\text { finance R }\end{array}$ & $\begin{array}{l}\text { - } \mathbf{R} \text { decides } \\
\text { on invest- } \\
\text { ment } \\
\text { - R decides } \\
\text { on price } \\
\text { - M decides } \\
\text { on price }\end{array}$ & $\begin{array}{l}\mathrm{R} \\
\text { repays } \\
\text { credit }\end{array}$ \\
\hline
\end{tabular}

Figure 1: Time structure 


\section{Figure 2a}

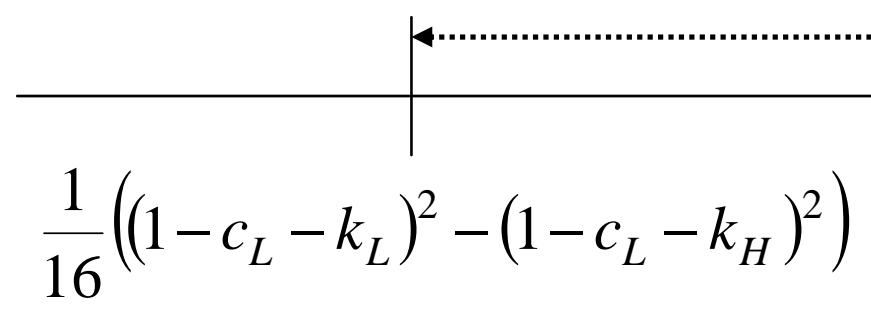

Assumption I1

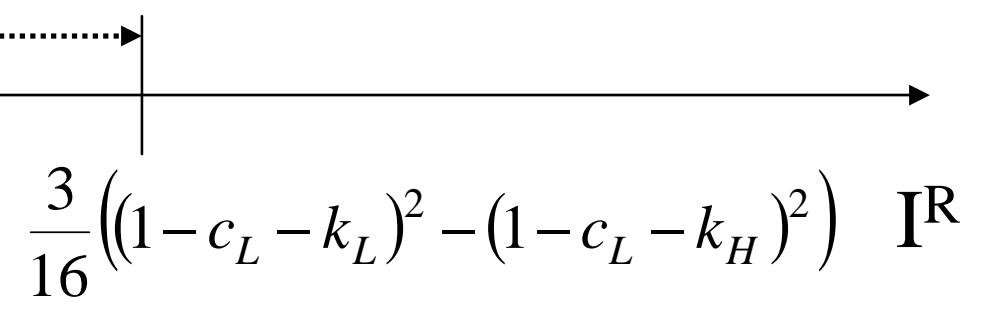

Assumption I2

\section{Figure $2 b$}

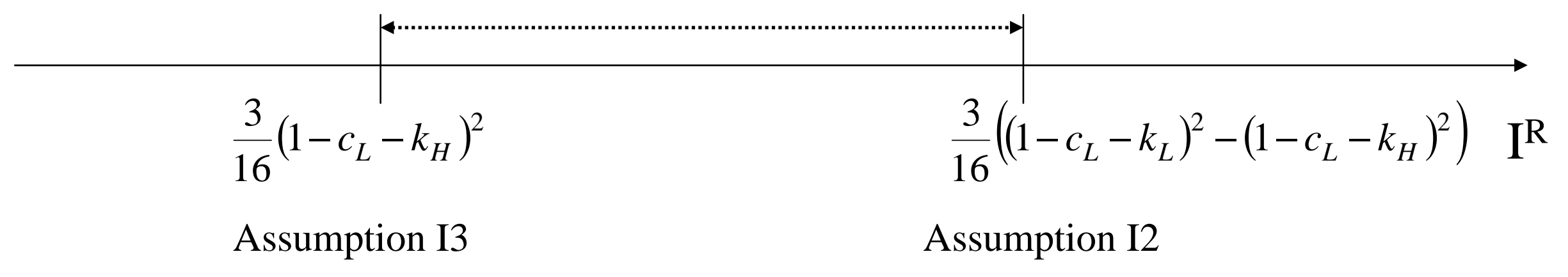

Figure 2: Illustration of the parameter space 


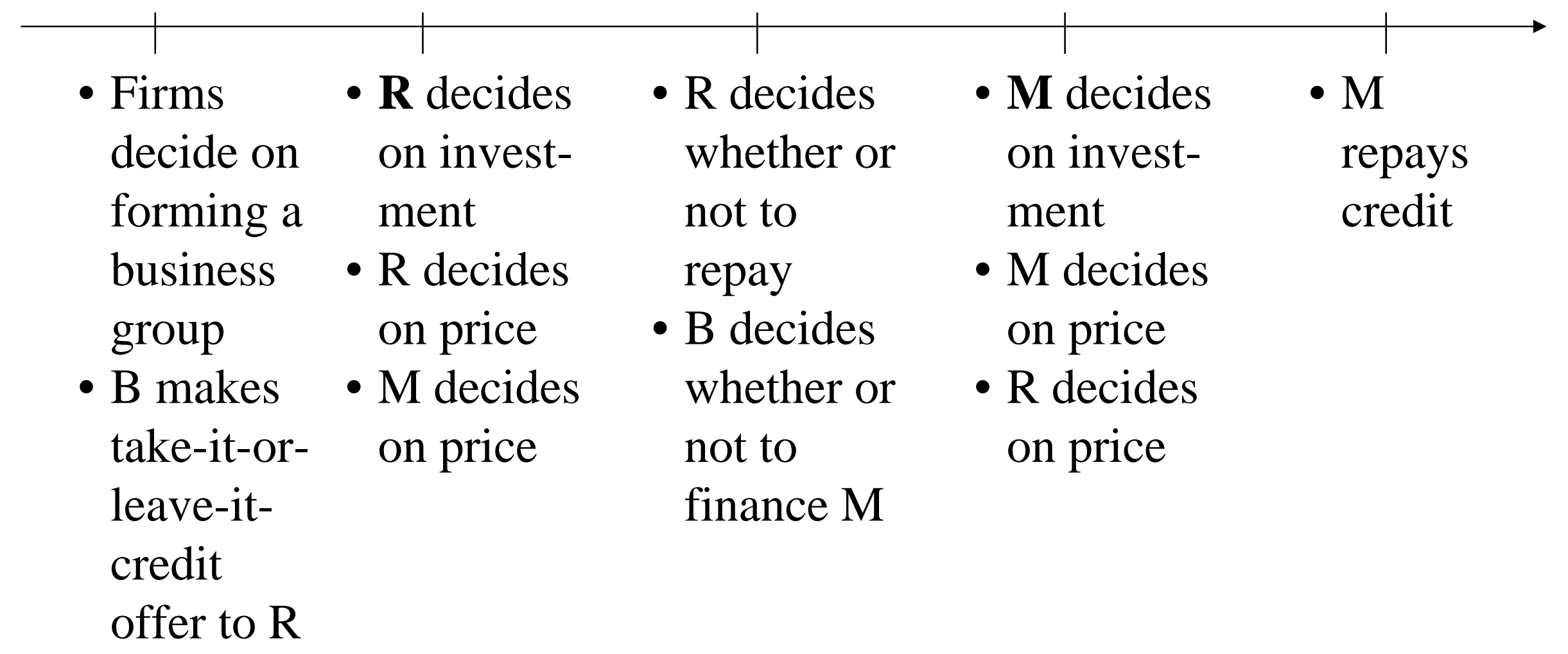

Figure 3: Time structure 